\title{
COARCTATION OF THE AORTA (ADULT TYPE) WITH RUPTURE DISTAL TO THE COARCTATION
}

\author{
BY \\ N. E. FRANCE, M.B., B.Ch., B. LEVIN, M.D., Ph.D., and B. McNICHOLL, \\ M.D., M.R.C.P., D.C.H. \\ From the Queen Elizabeth Hospital for Children, London
}

(Received for Publication, August 9, 1949)

Coarctation of the aorta is by no means an uncommon lesion. Two types are generally recognized (1) the infantile, in which there is a diffuse narrowing of the aorta between the origin of the left subclavian artery and the insertion of the ductus arteriosus, and (2) the adult type, in which the area of constriction is very narrow, and is situated at or close to the site of insertion of the ductus.

One of the most frequent causes of death is rupture of the aorta. As this is usually proximal to the coarctation it seemed of interest to report the following case of rupture distal to the coarctation, and to review similar cases previously reported.

\section{Case Report}

The patient, a boy aged 4 years, the third of three children, was born of healthy parents. There was no history of rubella during the pregnancy and birth was normal and at term, the weight being $7 \mathrm{lb} .3 \mathrm{oz}$. Development was normal. The only previous illness was measles at 1 year and the child also had occasional 'blue turns' associated with displays of temper. One month before admission to hospital the child had a mild attack of bilateral otitis media, and eight days before admission the present illness began with a gradual onset of lassitude and anorexia which persisted. On the third day a moderate degree of tonsillitis was found. Attacks of fever accompanied by profuse sweating and preceded by shivering, pallor, and increased lethargy then began. The attacks lasted about two hours and recurred several times a day until admission. The child was sometimes delirious in these attacks. The temperature fluctuated between normal and $102^{\circ} \mathrm{F}$. An unrecorded amount of sulphathiazole was given on the sixth, seventh, and eighth days. During this period there was no coryza or cough and no evidence that the child had been in pain.

On admission on the eighth day of his illness the child was pale and listless (temperature, $100^{\circ} \mathrm{F}$.). His weight was $42 \mathrm{lb}$. $6 \mathrm{oz}$. and development and nutrition were normal for his age. The tongue was coated but moist and mild tonsillitis without exudate was present.
There were no petechiae and the spleen was not palpable. No abnormality was found in the abdomen, the respiratory, or central nervous systems. There was marked arterial pulsation in the suprasternal region and capillary pulsation was seen in the nail beds. The radial pulses were equal and of high tension. No pulsation could be elicited in the femoral, dorsalis pedis, or posterior tibial arteries. The blood pressure in both arms was $150 / 100 \mathrm{~mm}$. Hg. The pressure in the lower limbs was not recorded. Vigorously pulsating vessels were easily palpable in the supra- and infrascapular regions, along the vertebral border of the scapula, and running along the lateral thoracic walls; systolic bruits were audible over the courses of these arteries. The deep epigastric arteries were not palpable.

The apex beat was maximal in the fourth intercostal space in the nipple line and was not markedly forcible; no thrills were palpable and percussion did not suggest any enlargement of the base of the heart. Well-marked, rough systolic murmurs of approximately equal intensity were heard at the apex and in the second and third spaces to the left of the sternum, the former being conducted slightly to the axilla; a short diastolic murmur was audible at the apex. The rhythm was normal.

Investigations. The urine was normal.

A throat swab on culture yielded only a scanty growth of Strep. viridans, diphtheroids, and $N$. catarrhalis.

Blood tests gave the following results:

E.S.R. $36 \mathrm{~mm}$. in one hour.

Haemoglobin $82 \%$ (Haldane).

Red blood count, 3,900,000 per c.mm. C.I. 1·05.

White blood count, 14,000 per c.mm.; stab forms $14 \%$ (1,960 per c.mm.); polymorphonuclear leucocytes $53 \%$ (7,420 per c.mm.); eosinophils 4\% (560 per c.mm.); lymphocytes $26 \%$ (3,640 per c.mm.); monocytes $3 \%$ (420 per c.mm.).

Blood urea, $22 \mathrm{mg}$. per $100 \mathrm{ml}$.

Blood cultures on the twelfth and thirteenth days were negative.

Dr. C. J. C. Hodson reported on a radiograph of the chest (Fig. 1) as follows:

- There is a moderate degree of cardiac enlargement affecting mainly the left ventricle. The aorta is left-sided. 
There is a vague blurring in the region of the arch which makes it impossible to assess its true size, but it would appear to be enlarged. The pulmonary

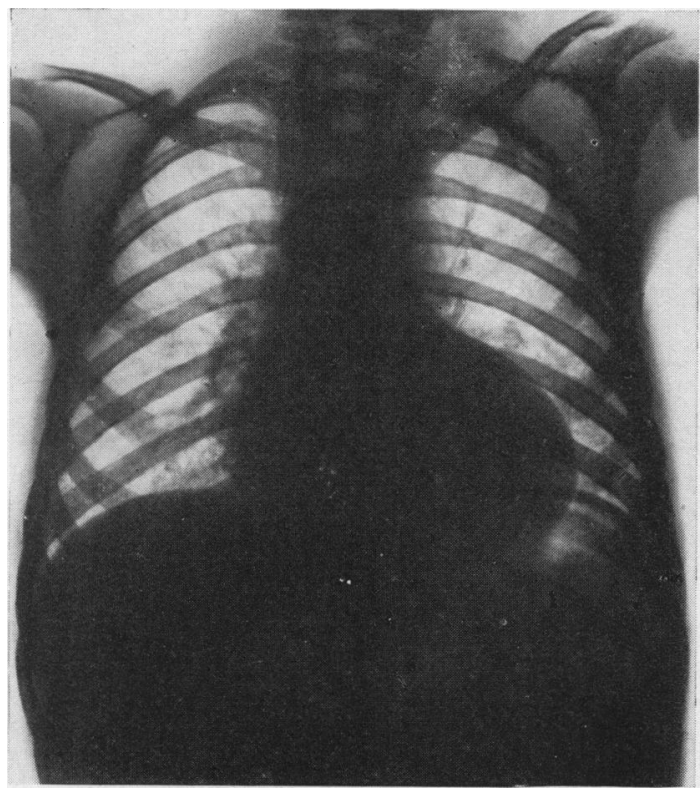

Fig. 1.-Postero-anterior view of chest showing blurred shadow in the aortic region.

vessels on the whole are less well developed than usual. No rib notching is seen. The left ventricular enlargement suggests an aortic or hypertensive lesion. But there is no definite sign, radiologically speaking, which gives the cause of this.'

Course of Illness. The temperature became normal for 12 hours following admission but rose again and continued to fluctuate between $98.4^{\circ} \mathrm{F}$. and $102^{\circ} \mathrm{F}$. during the next four days, the pulse and respiratory rates averaging 105 and 28 per minute respectively. On the thirteenth day slight clinical deterioration was accompanied by increased tachycardia. Intramuscular penicillin, 80,000 units four-hourly, was given after the second blood culture. Pyrexia continued next day and profuse sweating became frequent. There was some frequency of micturition but the urine showed only an occasional red or pus cell.

On the sixteenth day at 1 p.m. the child had a sudden paroxysm of coughing, became dyspnoeic, and sat up complaining of a pain referred to the right side; he cried and seemed distressed. He had a hoarse, croupy cough with some dyspnoea, and a moderate degree of inspiratory stridor which could not be definitely localized to the trachea or bronchus. There was moderate intercostal and subcostal recession with evidence of slight mediastinal displacement to the left. There was impairment of the percussion note and diminished air entry in the region of the left lower lobe and coarse rhonchi, mainly expiratory in nature, were heard over all areas of the chest. The child was not cyanosed or greatly distressed and slept at intervals. At 2 a.m. on the seventeenth day, another bout of coughing occurred during which about $12 \mathrm{oz}$. of fresh blood came from the mouth; moderate peripheral circulatory collapse followed. A slow transfusion of blood and morphine gr. 1/12 were given. During the succeeding hours the condition improved slightly though the stridor increased and the rib recession became more marked, particularly in the left basal region where it was associated with absent breath sounds. At 12.30 p.m. the child vomited another $10 \mathrm{oz}$. of fresh blood; peripheral circulatory failure and death followed shortly afterwards.

\section{Post-mortem Examination}

The post-mortem examination revealed only coarctation of the aorta just distal to an obliterated ductus

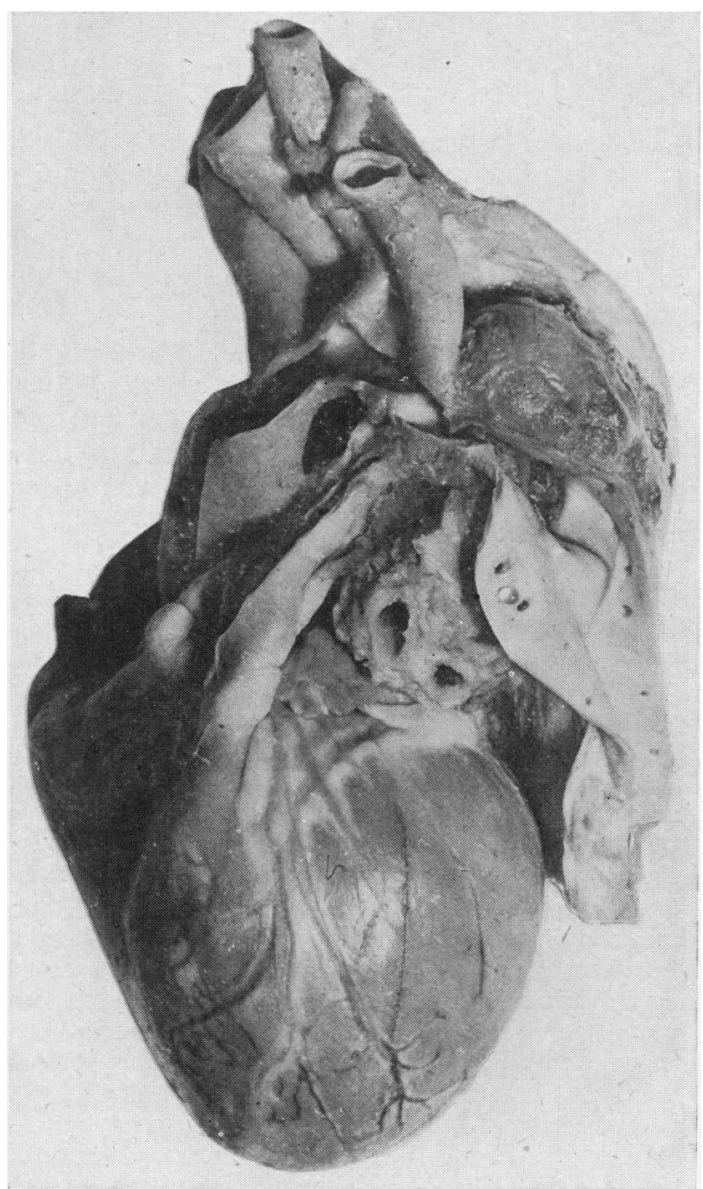

Fig. 2.-Heart and great vessels showing coarctation, tear of aorta, and false aneurysm.

arteriosus (Fig. 2), with infective endarteritis just beyond the coarctation and rupture forming a false aneurysm which had secondarily opened into the oesophagus. 
The aneurysm was filled with infected thrombus, the infective process extending into the wall of the oesophagus. Recent blood clot was seen in both main bronchi and in the stomach, and the small intestine contained a little altered blood.

Aorta. The ascending aorta was moderately dilated, gradually narrowing from a diameter of $1.5 \mathrm{~cm}$. at the aortic valve to $0.6 \mathrm{~cm}$. at the origin of the left subclavian artery. Near the orifice of the left coronary artery was a small patch of atheroma extending upwards for $1.5 \mathrm{~cm}$. as a narrow yellow streak. Immediately distal to the left subclavian artery the aorta was constricted by a circular shelf of tissue which projected into the lumen and reduced it to a tiny hole $2 \mathrm{~mm}$. in diameter.

The obliterated ductus arteriosus was represented by a band of dense fibrous tissue, $1.3 \mathrm{~cm}$. in length and $0.8 \mathrm{~cm}$. thick, which was attached to the lower border of the arch of the aorta almost opposite the origin of the left subclavian artery $2 \mathrm{~mm}$. on the proximal side of the constriction, and had produced a depression of the aortic wall $4 \mathrm{~mm}$. in diameter.

Immediately beyond the coarctation, the aorta widened abruptly to a diameter of $0.9 \mathrm{~cm}$. and remained approximately the same size throughout the remainder of its course. The descending aorta showed no evidence of atheromatous change. There was a transverse tear of the anterior wall of the descending aorta, $1.0 \mathrm{~cm}$. in length and situated $1.3 \mathrm{~cm}$. beyond the constriction, from which a longitudinal prolongation extended upwards to within $2 \mathrm{~mm}$. of the stenosis. This tear produced an opening measuring $1.6 \times 1.0 \mathrm{~cm}$. Immediately beyond the coarctation the intimal surface of the aorta was roughened by a number of tiny vegetations extending to the upper edge of the tear. While this upper edge was jagged with adherent blood clot, the lower edge was smooth and merged imperceptibly into the wall of the aorta. The lumen communicated through the torn wall with a false aneurysm measuring $3.4 \times 2.4 \mathrm{~cm}$. and filled with both old and recent blood clot. It lay in the mediastinum between the aorta and the oesophagus, displacing the latter to the right, and extended posteriorly to the right of the aorta. Inferiorly, it reached almost to the level of the second posterior intercostal arteries, and superiorly to the origin of the left subclavian artery. The wall of the oesophagus was ruptured by a longitudinal tear $3.5 \mathrm{~cm}$. in length, projecting from which was a haematoma measuring $4 \cdot 2 \times 2 \cdot 4$ cm. (Fig. 3).

Heart. The heart weighed $109 \mathrm{~g}$., and the left ventricle showed well-marked, concentric hypertrophy, its wall having an average thickness of $1.5 \mathrm{~cm}$. The left auricle was $3-5 \mathrm{~mm}$. thick and its mural endocardium was thickened. The aortic valve was bicuspid, both coronary arteries arising behind the left anterior cusp. The anterior cusp of the mitral valve was generally thickened and there were two small patches of atheromatous thickening near its attachment to the mitral ring. The chambers on the right side of the heart, the pulmonary artery, and the pulmonary and tricuspid valves were normal. There was no evidence of infective endocarditis.

The left coronary artery was $0.6 \mathrm{~cm}$. in diameter at its origin whilst the right coronary artery was $0.1 \mathrm{~cm}$. in diameter. The innominate artery, $1.0 \mathrm{~cm}$. in diameter, was of almost the same size as the arch of the aorta, and both the left common carotid and the left subclavian arteries measured $0.7 \mathrm{~cm}$. in diameter. The first right posterior intercostal artery was dilated to $3 \mathrm{~mm}$. at its origin and was then lost in the mediastinal blood clot. The other branches of the aorta were normal in size. No anomalous arteries were discovered.

Histology. The only abnormal findings in the structure of the aorta were in the regions of the coarctacion and the tear, with the exception of slight intimal

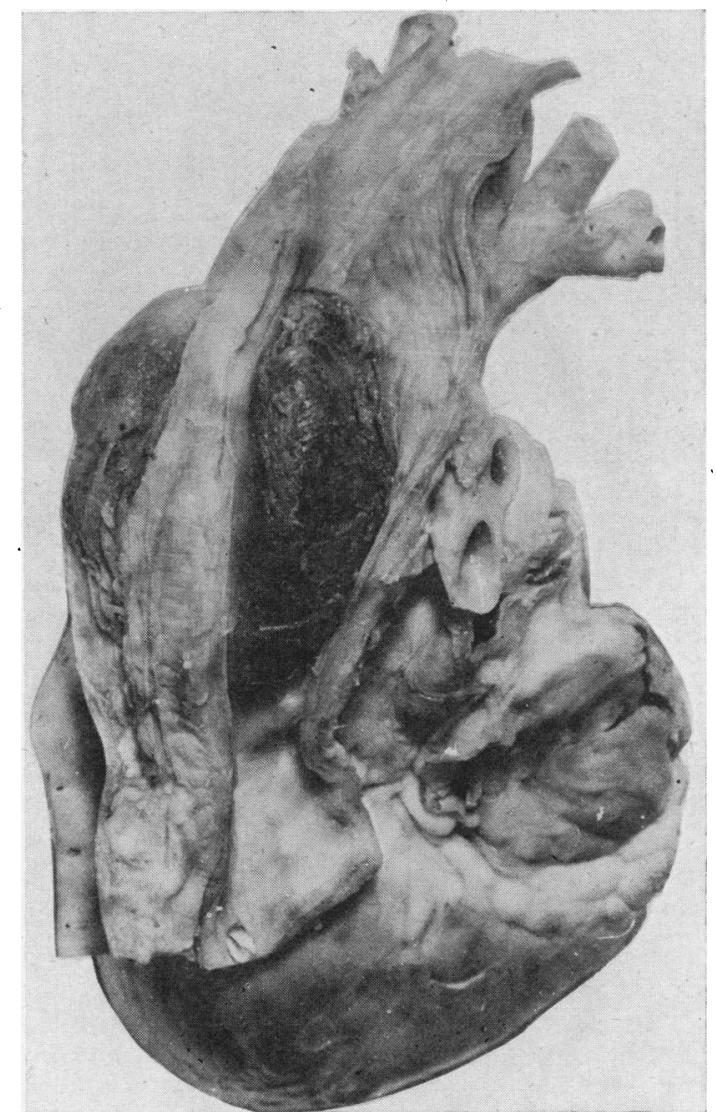

FIG. 3.-Torn oesophagus with haematoma projecting into its lumen.

thickening and subintimal fatty change in those areas of the ascending aorta which macroscopically resembled atheroma.

At the coarctation itself the projection into the lumen of the aorta showed normal media without any evidence of fibrosis or inflammatory exudation. The overlying subintimal connective tissue was thickened, especially on the distal side of the constriction where it extended over 3-4 mm. of the adjacent aorta. Near the upper limit of the tear in the aorta and about $3 \mathrm{~mm}$. beyond 


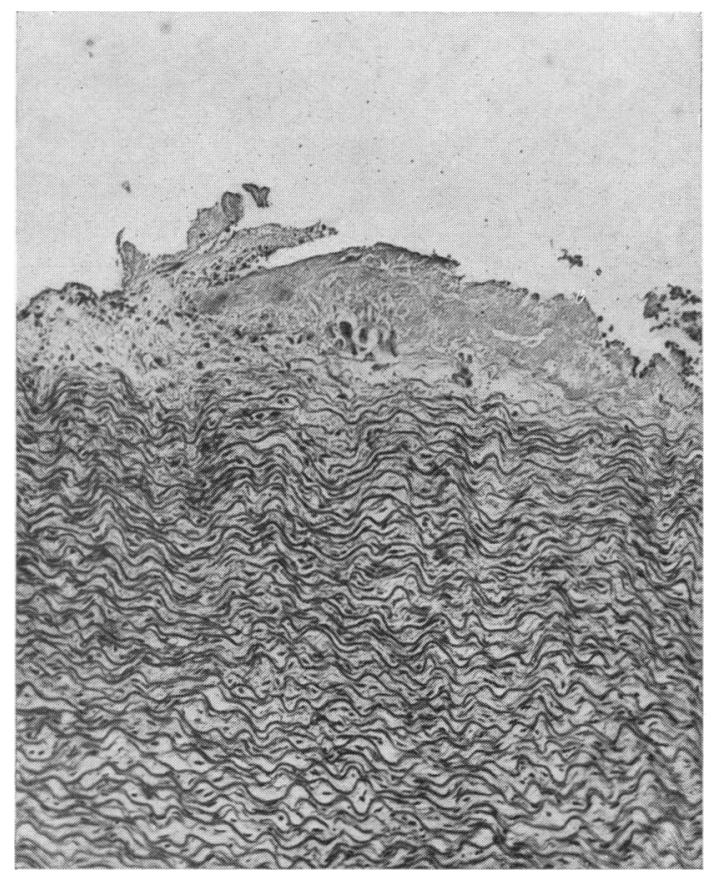

Fig. 4.-Section of aorta at the upper edge of the tear showing infective vegetation. $\times 80$.

the coarctation the intima disappeared and was replaced by a small, raised, granular mural thrombus in which fragments of elastic tissue and collagen could be distinguished (Fig. 4). The thrombus contained numerous Gram-positive cocci and showed a slight polymorphonuclear infiltration at its edge, whilst in its deeper regions were collections of large, elongated necrotic cells mainly arranged at right angles to the surface.

In the vicinity of the tear and lying between normal medial tissue, there were definite zones where the elastic fibres were separated and the intervening muscle fibres and connective tissue cells showed fatty change and necrosis. Two such layers could be distinguished near the upper edge of the tear and one broad band lay centrally in the media at the lower edge. The bands began at the tear itself and extended for $2-6 \mathrm{~mm}$. into the surrounding media. The areas were infiltrated by acute inflammatory cells, mainly neutrophil polymorphs with some eosinophils, which were most prominent in the zones adjoining the adventitia (Fig. 5). Here and there in the otherwise normal media were a few small nodules, superficially resembling Aschoff nodes, consisting of cells with round nuclei and indistinct cytoplasm. Wherever the aorta was in close contact with the mediastinal blood clot, the adventitia was disintegrated and infiltrated by an acute inflammatory exudate. The whole of the blood clot was heavily infiltrated with pus cells. Scattered throughout were fragments of elastic tissue and collagen with many small groups of Gram-positive cocci morphologically resembling staphylococci. These organisms were most noticeable in the superficial areas of the clot.

The ductus arteriosus showed normal obliteration of its lumen, but the surrounding connective tissue contained a moderate number of fibroblasts together with many small blood vessels and a light infiltration mainly of lymphocytes with some plasma cells. This process appeared to stop short at the aorta. There was no infiltration with similar cells or any inflammation in the aorta at the point of insertion and there was no evidence of spread of the fibrotic process to its wall.

The oesophagus was infiltrated with neutrophil polymorphs and a small number of eosinophils which were mainly found in the submucosa but in places they

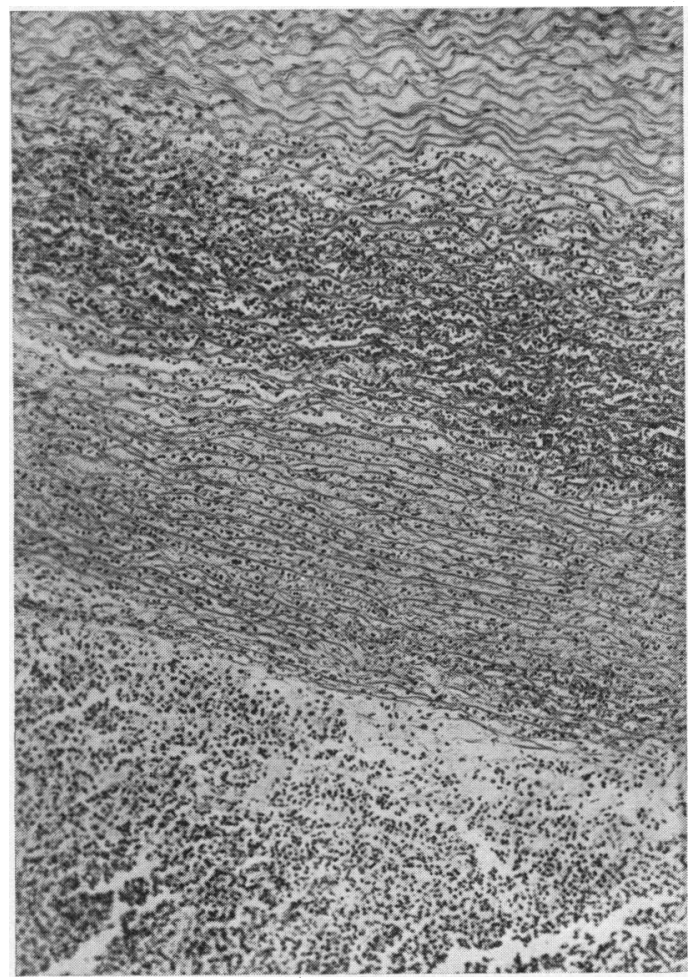

Fig. 5.-Section of aorta showing infected blood clot in the adventitia and inflammatory infiltration of the media. $\times 80$.

extended into both muscle coats and the squamous epithelium.

Apart from slight general thickening, the aortic cusps appeared normal. The subendocardial tissue of the left auricle was greatly thickened and the myocardium of both the left auricle and ventricle was obviously hypertrophied.

The right auricle and ventricle, the mitral valve, the pulmonary, coronary, innominate, left common carotid and left subclavian arteries were all histologically normal. 


\section{Discussion}

Clinical Findings in 13 Cases.-Clinical reports were available in 13 cases of rupture of the aorta distal to a coarctation. In seven the duration of symptoms was three months or less, while the remainder had had symptoms of cardiovascular disease for periods of four months to five years. In all but one of the latter cases, however, symptoms which could be attributed to serious aortic complications had been present for less than three months. The comparatively short history of a severe illness in these cases is in contrast to that found in uncomplicated cases of coarctation which generally present with fairly long and mild symptoms of hypertension or are discovered on routine examination. Periodic pain, often severe and apparently unrelated to effort, was a frequent complaint, occurring in eight cases; it was predominantly precordial in all of these but was sometimes referred to the left chest, shoulder, arm, or loin. Dyspnoea was reported to have been present for the duration of the illness in the same proportion of cases and to have occurred terminally in most. Cough, whether associated with respiratory infection or pressure upon the air passage, was a common finding. Haematemesis occurred terminally in seven cases, and in our patient was mistaken for a haemoptysis. Haemoptysis and painful dysphagia were also recorded, each in two instances. One patient presented with the clinical picture of dissecting aneurysm. The signs of coarctation in those cases in which it was diagnosed ante-mortem, did not differ from those found in uncomplicated cases. Aneurysms were apparent clinically in two cases on first examination, though one of these was possibly syphilitic in origin. Signs of poor aeration of the left lower lobe, presumably due to pressure on its bronchus, were mentioned in several cases, and haemothorax was present in three cases terminally.

When aortic endarteritis was present, the symptomatology was similar to that of bacterial endocarditis, but tended in some cases to be less well marked. In no case where rupture occurred were embolic lesions in the skin recorded, although they were frequently found in the spleen and kidney. On the other hand, in cases of endarteritis without rupture, petechiae and nodes were not uncommon and the signs of infection more definite. Endarteritis was possibly secondary to otitis media in one case, to dental extraction in another, and to tonsillectomy in a third; upper respiratory infection was present in several cases though it was not clear what relationship it bore to the onset of the endarteritis. Adequate chemotherapeutic or antibiotic prophylaxis is necessary before operations on these patients. Any unexplained pyrexia or illness must be regarded as possibly due to endarteritis.

It would appear that the symptoms of endarteritis in the presence of coarctation of the aorta are little different from those in bacterial endocarditis. Aneurysmal dilatation or impending rupture should be suspected when pains similar to those described above are a prominent feature.

The coarctation was diagnosed during life in six of the thirteen cases of rupture distal to the stenosis, while in seven cases of endarteritis without rupture a definite diagnosis of coarctation was made in only one case, though endocarditis had been suspected in all. Of the ten cases with radiological reports, the diagnosis was made in five.

Radiological Findings. Radiological findings were reported in 10 of the 13 cases. In four cases aortic aneurysms were visualized, one being situated 'at the left hilum,' one occupying most of the left upper zone and one 'at the right hilum '; the fourth, at the left hilum, was associated with a ' large aortic knob.' Two cases showed opacities in the left hilar region, one being associated with an absent aortic knob and the other with an opacity involving most of the left upper zone which at necropsy proved to be a large haematoma in the upper lobe. A widened ascending aorta was mentioned in two further cases and a ' large aortic knob' in another. In view of the necropsy findings in our patient, the unusual appearance in the aortic arch region probably represented the para-aortic haematoma. Since absence of the aortic knuckle is the usual finding in uncomplicated cases of coarctation, although it may be simulated by an enlarged left subclavian artery (Crafoord, 1945), these reports would suggest that all unusual appearances in this region should be investigated with the possibility of aneurysmal dilatation or rupture in mind. With modern techniques, particularly angiocardiography, it should be possible, in known cases of coarctation, to detect the earliest evidence of dilatation or rupture of the aorta.

With the advent of surgical treatment as an established procedure in suitable cases of coarctation, the diagnosis, prognosis, and treatment of infective lesions of the aorta became of greater importance. If endarteritis is suspected or diagnosed before radiology reveals any significant degree of aortic dilatation, it is possible that early intensive treatment may effect a cure and prevent such severe damage to the aorta as to preclude surgical measures. Once an aneurysm has formed, it is still possible that intensive therapy may completely heal the lesion, though the condition of the aorta may be 
much less favourable for surgery. That this is possible is shown by a report of Nicholson (1940) where in a child of ten years, a mycotic aneurysm below the coarctation underwent spontaneous resolution and showed signs of calcification four years later. When rupture has occurred, even if minimal in extent, it is doubtful if treatment can do more than delay the course of events. Although the present case received adequate penicillin for the treatment of most cases of bacterial endocarditis in a child of four years, necropsy revealed that penicillin had had little effect upon the course of the disease.

Pathogenesis of Rupture in Coarctation of the Aorta. Abbott (1928) gives rupture of the aorta as the cause of death in 40 cases $(20 \%)$ of her series of 200, and Reifenstein, Levine, and Gross (1947) in 24 cases $(23.1 \%)$ of 104 . In most of these the rupture has been in the ascending aorta. Up to 1946 only 16 cases of rupture distal to the stenosis had been reported, ten cases of so-called 'spontaneous' rupture, and six cases of rupture following mycotic endarteritis.

Table 1 is an analysis of the number of cases of rupture of the aorta reported $(a)$ as spontaneous, and $(b)$ as due to ruptured mycotic aneurysm.

Since Reifenstein's review two further cases of spontaneous rupture have been reported (Lenegré and de Brux, 1945).

Table 1 shows that rupture of the aorta distal to the coarctation is much less frequent than rupture proximal to it (16 cases of the former as against 56 of the latter in the combined series). It is to be noticed that there were only three cases of aortitis proximal to the coarctation, of which two ruptured. There were altogether 21 cases of aortitis distal to the coarctation occurring either alone or together with endocarditis, of which six had undergone rupture. In addition, there were ten cases of the rupture distal to the coarctation, which were classified by Abbott and Reifenstein as 'spontaneous.' However, a review of the cases so classified suggests that this may be misleading.

It does not seem surprising that rupture should occur in the ascending aorta. The increased blood pressure developing in this region would be expected to lead to secondary effects: dilatation of the ascending aorta and atheroma, with weakening of the wall and degeneration of the media. In the majority of cases of rupture these changes are present. Microscopically, the media shows thinning, with a decrease and interruption in the elastic tissue, increase in connective tissue and hyaline and fatty change. These changes may, however, be due in part to a congenital defect of the media (Turnbull, 1915; Abbott, 1928). Any sudden increase of pressure in the aorta, acting at the site of election just above the aortic cusps, might cause a tear. It is significant that in most of these cases a dissecting aneurysm is first formed, followed at an interval of some hours or days by its rupture.

It is not so obvious, however, why rupture should occur distal to the coarctation. The increase of pressure which may modify the structure of the ascending aorta is absent beyond the stenosis, so that similar degenerative changes are less likely to be produced. If the congenital defect be a predisposing cause, it is difficult to understand why the rupture should not have occurred in the ascending aorta, since this defect of the media is general and it is in this region that the wall is subjected to a considerably greater strain. Atheroma of the descending aorta with or without medial degeneration is a frequent finding in the older subject, independently of the presence of the coarctation. If either of these causes operated, it would be expected that in most cases a dissecting aneurysm would be formed, and it is perhaps significant that in the man aged 62 years with rupture some distance below the stenosis (Hecker, 1939), this did, in fact, occur.

A third predisposing cause may be destruction by infection of muscular and elastic tissue of the aorta. Such a process may involve the media either by the lodgement of infected emboli in the vasa vasorum or by extension from an infective endarteritis of the aorta. The former was suggested by Narr and Johnson (1934) to explain rupture of the ascending aorta in their case of a boy aged seven years. When infection of the aorta is present, it is almost invariably found immediately beyond the coarctation, and it is difficult to believe that an embolus would select such a limited area in which to settle. It is our view that this condition always begins with intimal involvement. For this to occur there must be some predisposing condition of the intima of the aorta which renders it susceptible to infection. Grant and his colleagues (1928) discovered small thrombi on the valves of the heart, especially where these were deformed by previous rheumatism or showed congenital anomalies. They considered that these thrombi formed a suitable foothold for circulating bacteria. More recently, Duguid (1948) has showed that similar thrombi are commonly found on the intimal surface of the aorta. Should these arise immediately beyond the coarctation where the blood flow must be considerably reduced and may be altered in direction, they would form a suitable nidus for the growth of organisms. The resultant weakening of the wall may be followed either by the formation of a saccular aneurysm or 
TABLE 1

Incidence of Rupture of Aorta and Aortitis in Coarctation of Aorta of Adult Type

\begin{tabular}{|c|c|c|c|c|c|c|c|c|}
\hline \multirow[b]{2}{*}{ Author } & \multirow[b]{2}{*}{$\begin{array}{l}\text { Total No. } \\
\text { of Cases of } \\
\text { Coarctation }\end{array}$} & \multicolumn{3}{|c|}{ Proximal to Coarctation } & \multicolumn{4}{|c|}{ Distal to Coarctation } \\
\hline & & $\begin{array}{l}\text { Total No. } \\
\text { of Cases of } \\
\text { Rupture }\end{array}$ & $\begin{array}{l}\text { Aortitis } \\
\text { and } \\
\text { Rupture }\end{array}$ & $\begin{array}{l}\text { Aortitis } \\
\text { without } \\
\text { Rupture }\end{array}$ & $\begin{array}{l}\text { Total No. } \\
\text { of Cases of } \\
\text { Rupture }\end{array}$ & $\begin{array}{l}\text { Spon- } \\
\text { taneous } \\
\text { Rupture }\end{array}$ & $\begin{array}{l}\text { Aortitis } \\
\text { and } \\
\text { Rupture }\end{array}$ & $\begin{array}{l}\text { Aortitis } \\
\text { without } \\
\text { Rupture }\end{array}$ \\
\hline \multirow{3}{*}{$\begin{array}{l}\text { Abbott } \\
\text { Reifen- } \\
\text { stein }\end{array}$} & 200 & 36 & 1 & 0 & 8 & 3 & 5 & 8 \\
\hline & $103^{*}$ & 20 & 1 & 1 & 8 & 7 & 1 & 7 \\
\hline & & 56 & 2 & 1 & 16 & 10 & 6 & 15 \\
\hline
\end{tabular}

* One case (Evans, 1933) is cited in Reifenstein's series, and is quoted also in Abbott's series (Turnbull, 1915).

rupture into the mediastinum and a false aneurysm. The infection may spread to neighbouring tissues or pressure may lead to atrophy with final rupture of the aneurysm into such structures as the bronchus, oesophagus, and pleural sac. This sequence of events is to some extent borne out by a study of the reported cases of aortitis without ruptures. Some authors record friable vegetations only (Babington, 1847; Kretz, 1895; Mackenzie, 1927; de la Chapelle and Graef, 1931; Walker and Livingstone, 1938). Focken (1924) found ulceration in addition to vegetations in both his cases; Fawcett (1905) and Poynton and Sheldon (1928) found definite bulging of the aorta. Saccular aneurysms were present in the cases reported by Kellog and Biskind (1934) and by Bauer and Iverson (1945). In our case, it is almost certain that infection began on the intima of the aorta, a false aneurysm was produced, and the wall of the oesophagus was finally eroded with a subsequent fatal haemorrhage.

It is probable that the presence of an established infection of the aortic valve will predispose to aortitis. Of ten cases of aortitis in Reifenstein's series (table 1), four had aortic endocarditis, whereas of 93 cases of coarctation without aortitis in the same series, only 11 had aortic endocarditis.

It is interesting to note that in spontaneous rupture of the aorta due to accident injuries, the site of the tear has frequently been observed (Tannenbaum and Ferguson, 1948) as just above the aortic cusps and just distal to the attachment of the ligamentum arteriosum. Direct experiment has shown (Oppenheim, 1918) that at a pressure of $3,000 \mathrm{~mm} . \mathrm{Hg}$, the normal aorta will sustain rupture at one or other of these sites. These positions are points at which the aorta is relatively fixed, one by the heart and the other by the ligamentum arteriosum which is attached to the structures at the root of the lung. These correspond to the usual sites of rupture in coarctation of the aorta. It appears probable that when the wall of the aorta is weakened at either of these points an increase of arterial pressure, which would be without effect on the normal vessel, is sufficient to rupture a diseased artery.

Eighteen Cases of Rupture Distal to Coarctation. In an attempt to evaluate the part played by high blood pressure, congenital defect of the media, and infection, a review of reported cases of rupture of the aorta distal to the coarctation was made. Table 2 shows the relevant details of the 18 cases of rupture. One other case of rupture (Bargi, 1934) distal to the coarctation has been reported, but as the original communication is not available it has not been included.

SEX AND Age. As in coarctation of the aorta generally, there is in this series a much larger proportion of males than females (approximately four to one). The average age of death from rupture distal to the aorta, when the rupture followed aortitis, was $17 \cdot 3$ years, whereas when the rupture was spontaneous, it was 37 years. The significant difference in the average age at death in these two groups seems to support the conclusion that the cause of the rupture in each type of case is different. This may be compared with the average age at death of 33.5 years in Abbott's 200 cases, and 35.0 years in Reifenstein's series. It is interesting to note that the average age at death of 13 cases of aortitis distal to the coarctation without rupture was 20 years. It would be expected that in rupture due to medial degeneration the average age would be higher than in rupture following aortitis, as this group would include a certain number of cases of atheroma, in which the degeneration was unrelated to the coarctation.

Bicuspid Valves. The condition of the aortic valve was mentioned in only ten cases, in four of which they were said to be bicuspid. If it is assumed that this anomaly was not present in those five cases where the condition of the valve was not mentioned, the incidence of bicuspid valves in this 
TABLE 2: RUPTUR

Group A. 17 Years of Age and Under (seven cases)

\begin{tabular}{|c|c|c|c|c|}
\hline Present authors & $\begin{array}{c}\text { Male } \\
4 \\
\end{array}$ & + & Slight atheroma & Rupture of false aneurysm \\
\hline Smith and Targett & $\underset{9}{\text { Male }}$ & & & Rupture of aorta formed a false aneurysn \\
\hline $\begin{array}{l}\text { Moragues et al. } \\
(1942)\end{array}$ & $\begin{array}{c}\text { Male } \\
11\end{array}$ & - & & Rupture of saccular aneurysm $\overrightarrow{\vec{\omega}}$ \\
\hline Libman (1928) & $\underset{12}{\text { Female }}$ & & & Rupture of mycotic aneurysm \\
\hline Group B. Over 17 & Years of Age & cases) & & - \\
\hline $\begin{array}{l}\text { Barsantini and } \\
\text { Bozzano (1938) }\end{array}$ & $\underset{24}{\text { Male }}$ & + & $\begin{array}{c}\text { Slight dilatation } \\
\text { Marked } \\
\text { atheroma } \\
\end{array}$ & Large tear of aorta \\
\hline $\begin{array}{l}\text { Lenegré and } \\
\text { de Brux's Case } 1 \\
(1945)\end{array}$ & $\underset{24}{\text { Male }}$ & & & Rupture of dissecting aneurysm \\
\hline $\begin{array}{l}\text { Zaslow and } \\
\text { Krasnoff (1943) }\end{array}$ & $\begin{array}{c}\text { Male } \\
25\end{array}$ & - & Normal & $\begin{array}{l}\text { Rupture of dilated aorta well beyph } \\
\text { constriction }\end{array}$ \\
\hline Koletsky (1942) & $\underset{38}{\text { Male }}$ & & & $\begin{array}{l}\text { Rupture of saccular aneurysm which } \\
\text { showed large friable vegetations }\end{array}$ \\
\hline $\begin{array}{l}\text { Lenegré and } \\
\text { de Brux, Case } 2\end{array}$ & $\underset{41}{\text { Female }}$ & & & Rupture of saccular aneurysm \\
\hline $\begin{array}{l}\text { Carney Hospital } \\
\text { Records (1947) }\end{array}$ & $\underset{45}{\text { Male }}$ & & & $\begin{array}{l}\text { Rupture of aorta forming dissecting } \\
\text { aneurysm }\end{array}$ \\
\hline Kriegk (1878) & $\underset{48}{\text { Male }}$ & 一 & & $\begin{array}{l}\text { One tear above and another below leading } \\
\text { into dissecting aneurysm }\end{array}$ \\
\hline Hecker (1939) & $\underset{62}{\text { Male }}$ & & & $\begin{array}{l}\text { Tear of dilated aorta } 6 \text { in. below cons } \\
\text { striction, forming dissecting aneurysm }\end{array}$ \\
\hline & & & & 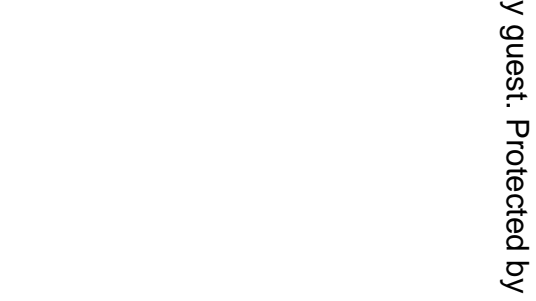 \\
\hline
\end{tabular}


Distal to Coarctation

\begin{tabular}{|c|c|c|c|}
\hline \multicolumn{4}{|l|}{ Aorta } \\
\hline Microscopy & Organism & Coarctation & Remarks \\
\hline Near tear: Infective endarteritis & Staphylococcus & Extreme & Rupture of mycotic aneurysm \\
\hline Rupture of intima and media & & Extreme & $\begin{array}{l}\text { Probably rupture of mycotic aneurysm, } \\
\text { since there were inflammatory adhesions } \\
\text { around it. }\end{array}$ \\
\hline $\begin{array}{l}\text { Necrosis of wall of aorta with abscess } \\
\text { formation }\end{array}$ & Pneumococcus & Extreme & Rupture of mycotic aneurysm \\
\hline \multirow{2}{*}{$\begin{array}{l}\text { Vegetations showed inflammatory cells. } \\
\text { Wall infiltrated by inflammatory cells. }\end{array}$} & None seen & Extreme & Probably rupture of mycotic aneurysm \\
\hline & $\begin{array}{c}\text { Strep. } \\
\text { anhaemolyticus }\end{array}$ & & $\begin{array}{l}\text { Rupture of mycotic aneurysm. } \\
\text { Chills and Sweats, five weeks before } \\
\text { death }\end{array}$ \\
\hline $\begin{array}{l}\text { Aorta small and thin walled below } \\
\text { aneurysm otherwise normal }\end{array}$ & & Extreme & $\begin{array}{l}\text { Signs of severe infection for three months } \\
\text { before death. Splenic and renal infarcts } \\
\text { present. Rupture of mycotic aneurysm }\end{array}$ \\
\hline Aorta near aneurysm normal & Strep. viridans & Moderate & $\begin{array}{l}\text { Bacterial endocarditis of aortic and mitral } \\
\text { valves. Rupture of mycotic aneurysm }\end{array}$ \\
\hline
\end{tabular}

\begin{tabular}{|c|c|c|c|}
\hline . & & Extreme & Probably spontaneous rupture \\
\hline $\begin{array}{l}\text { No medial degeneration. Endarteritis } \\
\text { obliterus of vasa vasorum }\end{array}$ & & Moderate & Spontaneous rupture \\
\hline \multirow[t]{4}{*}{$\begin{array}{l}\text { Mucinous degeneration of media. No } \\
\text { evidence of syphilis or atheroma }\end{array}$} & & Moderate & Spontaneous rupture \\
\hline & & Extreme & $\begin{array}{l}\text { Spontaneous rupture due to traction by } \\
\text { ligamentum arteriosum. No evidence of } \\
\text { infection microscopically }\end{array}$ \\
\hline & Strep. viridans & Extreme & $\begin{array}{l}\text { Rupture of mycotic } \\
\text { cerebral haemorrhage. } \\
\text { Wassermann } \\
\text { Strongly positive } \\
\text { endocarditis }\end{array}$ \\
\hline & & Extreme & Spontaneous rupture due to atheroma \\
\hline $\begin{array}{l}\text { Marked thinning and interruption of } \\
\text { elastica. Infiltration with polymorphs }\end{array}$ & $\begin{array}{l}\text { Haem. staph. } \\
\text { albus }\end{array}$ & & Rupture of mycotic aneurysm \\
\hline \multirow[t]{4}{*}{$\begin{array}{l}\text { Medial necrosis and fibrosis of aorta. } \\
\text { Vasa vasorum partly obliterated. No } \\
\text { definite evidence of syphilis }\end{array}$} & & $\begin{array}{l}\text { 'Slightly } \\
\text { narrowed" }\end{array}$ & $\begin{array}{l}\text { Spontaneous rupture. Possibly syphilitic } \\
\text { in origin. (Strongly positive Wassermann } \\
\text { reaction) }\end{array}$ \\
\hline & & Moderate & $\begin{array}{l}\text { Spontaneous rupture. Death from con- } \\
\text { gestive cardiac failure } 18 \text { months after } \\
\text { rupture }\end{array}$ \\
\hline & & Moderate & $\begin{array}{l}\text { Spontaneous rupture possibly produced by } \\
\text { kinking due to traction by ligamentum } \\
\text { arteriosum }\end{array}$ \\
\hline & & Extreme & Spontaneous rupture. Death by suicide \\
\hline
\end{tabular}


series was $22.2 \%$ Abbott (1928) reports the incidence as $23.5 \%$ and Reifenstein (1947) as $42 \cdot 3 \%$. The high incidence of bicuspid valves will obviously predispose to bacterial endocarditis, and as has been shown above, to aortitis.

Degrie of Stenosis. According to Abbott's classification of moderate, extreme, and complete stenosis, there were six cases of moderate, and ten of extreme stenosis whilst there were no cases of complete atresia. Abbott (1928) found seven cases of moderate and 15 of extreme stenosis, and 11 of complete atresia in 33 cases of rupture of the ascending aorta. There seems to be no adequate explanation for the absence of rupture distal to the coarctation in cases of complete atresia.

AORTA. In nine cases where the ascending aorta was mentioned there was atheroma in three cases, and it was stated to be absent in two. There was slight dilatation of the ascending aorta in two instances, hypoplasia in one, and it was of normal size in four cases. Similarly the descending aorta appeared to show no atheroma in most cases and this would indicate that atheroma played no significant part in the aetiology of the ruptures. There was dilatation of the descending aorta in six cases, with the formation of a fusiform or a saccular aneurysm not obviously due to endarteritis

Site ANd Character of Tear. In two instances an aneurysm was possibly first formed by the traction of the ligamentum arteriosum at its insertion into the wall of the aorta and this aneurysm had then ruptured. In four other cases, a dissecting aneurysm had formed, in one of which it was situated 6 in. below the coarctation in the descending aorta. In six cases, mycotic aneurysms were definitely stated to be present and these had ruptured. In three instances a saccular aneurysm, the wall of which was formed in the most part by blood clot, had ruptured. In two of these inflammatory adhesions or vegetations were also of mycotic origin. In all but two cases, the tear was just below the coarctation, which has been shown to be one of the sites of election for rupture and is, moreover, the commonest site of endarteritis in coarctation.

Mycotic Endarteritis. In five cases the cause of death was stated to be a rupture of a mycotic aneurysm, and in each of these, the causative organism was identified; it was different in each case. In one other case of rupture of mycotic aneurysm from which Strep. viridans was isolated, death was due to cerebral haemorrhage. That mycotic endarteritis was present in three other cases is probable, since in two cases vegetations or adhesions were observed, and in the last case tonsillectomy (for chronic tonsillitis) had been performed ten days previously, and at necropsy splenic and renal infarcts were found.

A consideration of these cases supports the conclusion that rupture of the aorta distal to the coarctation appears in many cases to be different in origin from rupture proximal to the aorta. Mycotic endarteritis is very rare in the latter, and rupture is almost always due to the wall of the aorta being weakened by the effects of high blood pressure. In the former, mycotic endarteritis is present in $50 \%$ of the cases with resultant weakening of the aorta and rupture. This occurred in the younger age group. In the remainder, the reason for the rupture is more obscure. Congenital defect of the media may be a factor, and, although atheroma was not mentioned in the majority of cases, it might well be assumed that some degree of atheroma was present, especially as the average age of this group was much higher than in the group of mycotic endarteritis.

\section{Summary}

A case of rupture of the aorta distal to coarctation in a boy aged four years is reported.

The clinical findings and pathogenesis of rupture of the aorta distal to coarctation are discussed and all the cases previously reported are reviewed.

The importance of the prevention of endarteritis, and of its early diagnosis and treatment in such cases is emphasized.

It is concluded that of the three predisposing factors, mycotic endarteritis plays a much greater part in the aetiology of rupture distal to the coarctation than in rupture of the ascending aorta proximal to it.

We wish to thank Dr. N. M. Jacoby for permission to publish the case, Dr. C. J. C. Hodson for criticism of the section on radiological findings, Dr. H. H. M. Mackay for her help and criticism, Dr. Elsie Gibbons for her careful clinical notes, and the Southern Group Laboratory for the photographs.

\section{REFERENCES}

Abbott, M. E. (1928). Amer. Heart J., 3, 381 and 574. Babington, W. (1847). Trans. path. Soc., London, 1, 55. Bargi, L. (1934). Clin. med. ital., 65, 152.

Barsantini, J. C., and Bozzano, J. J. (1938). Arch. uruguay Med., 13, 448.

Bauer, D. de F., and Iverson, L. (1945). Amer. Heart J., $30,30$.

Beneke (1922). Münch. med. Wschr., 69, 413.

'Carney Hospital Records' quoted by Reifenstein, G. H., Levine, S. A., and Gross, R. E. (1947). Amer. Heart. J., 33, 146.

Chappelle, C. E. de la, and Graef, I. (1931). Med. Clin. N. Amer., 14, 1335.

Crafoord, C., and Nylin, G. (1945). J. thorac. Surg., 14, 347. 
Duguid, J. B. (1948). J. Path. Bact., 60, 57. Evans, W. (1933). Quart. J. Med., N.S., 2, 1. Fawcett, J. (1905). Guy's Hosp. Rep., 59, 1.

Focken, E. (1924). Z. Klin. Med., 100, 179.

Goodson, W. H. jnr. (1937). New Engl. J. Med., 216, 339.

Grant, R. T., Wood, J. E. jnr., and Jones, T. D. (1928). Heart, 14, 247.

Hecker, J. T. (1939). J. Iowa med. Soc., 29, 240.

Kellogg, F., and Biskind, G. R. (1934). Calif. Med., 40, 368.

Koletsky, S. (1942). Ohio St. med. J., 38, 465.

Kriegk, M. (1878). Vischr. prakt. Heilk., 137, 47.

Kretz, R. (1895). Wien klin. Wschr., 8, 24.

Lenegré, J., and Brux, J. de (1946). Arch. Mal. Coeur., $39,168$.

Leudet, E. (1858). Gaz. Méd. France, 13, 44.

Libman, E. (1928). Quoted by Abbott, M. E.; in Blumer, G. (1928). ' Bedside Diagnosis,' II, 376. Philadelphia.

Mackenzie, G. M. (1927). Amer. J. med. Sci., 164, 87.

Moragues, V., Moore, L. T., and Rossen, J. A. (1942). Amer. Heart J., 24, 828.
Mönckeberg, G. (1907). Verhandl. dtsch. path. Ges., 11, 267.

Narr, F. C., and Johnson, E. T. (1934). Amer. J. Dis. Child., 47, 91.

Nicholson, G. H. B. (1940). Amer. Heart J., 20, 357.

Oppenheim, F. (1918). Münch. med. Wschr., 65, 1234.

Poynton, F. J., and Sheldon, W. P. H. (1928). Arch. Dis. Childh., 3, 191.

Reifenstein, B. W. (1924). Amer. J. med. Sci., 168, 381.

Reifenstein, G. H., Levine, S. A., and Gross, R. E. (1947). Amer. Heart J., 33, 146.

Smith, F. J., and Targett, J. H. (1897). Trans. path. Soc., London, 48, 53.

Smith, F. M., and Hansmann, G. H. (1926). Arch. intern. Med., 38, 367.

Tannenbaum, I., and Ferguson, J. A. (1948). Arch. Path., 45, 503.

Turnbull, H. M. (1915). Quart. J. Med., 8, 201.

Walker, J. B., and Livingstone, F. D. M. (1938). Lancet, 2, 660 .

Zaslow, J., and Krasnoff, S. O. (1943). Amer. Heart J., $26,832$. 